\title{
Effect of seed coating treatments on Longevity of Wheat (Triticum aestivum L.) seeds
}

\author{
Radhika Chaturvedi*, Karam Chand Dhiman, Rajesh Kanwar and Manisha Thakur \\ CSK Himachal Pradesh Krishi Vishvavidyalaya Palampur, Himachal Pradesh-176 062, India
}

\section{Article history:}

Received: 19 July, 2021

Revised: 07 Aug., 2021

Accepted: 11 Aug., 2021

\section{Citation:}

Chaturvedi R, KC Dhiman, R Kanwar and $M$ Thakur. 2021. Effect of seed coating treatments on longevity of wheat (Triticum aestivum L.) seeds. Journal of Cereal Research 13 (Spl-1): 57-66. http://doi.org/10.25174/2582$\underline{2675 / 2021 / 114886}$

*Corresponding author:

E-mail: radhikachaturvedi221@gmail.com

(c) Society for Advancement of Wheat and Barley Research

\begin{abstract}
The experiment was conducted to evaluate the effect of different seed coating treatments on seed longevity and further to identify the effective seed coating treatment for enhancing seed longevity in wheat seeds. The seeds of wheat variety HPW-155 were coated with nine different treatments comprising of polymer, fungicide, insecticide, polymer-fungicide and polymer-insecticide combinations. The treated and untreated seeds were stored in three replications for twenty-four months after packing in HDPE (high density polyethylene) interwoven non-laminated bags. The evaluation of seed quality parameters was made at bi-monthly intervals for twelve months. The experiment revealed that irrespective of seed coating, seed deteriorated and the vigour declined with aging of seeds. Amongst various treatments, seed coated with polymer @ $3 \mathrm{ml}$ per $\mathrm{Kg}$ of seed + Vitavax $200 @ 2 \mathrm{~g}$ per $\mathrm{Kg}$ of seed $\left(\mathrm{T}_{6}\right)$ was found superior for quality parameters viz, germination percentage $(93.00 \%)$, speed of germination $(18.45)$, seedling length $(16.06 \mathrm{~cm})$, seedling dry weight $(0.0116 \mathrm{~g})$, seedling vigour index - I (1494), vigour index -II (1.079) and field emergence (82.00\%) at the end of 24 months of storage over untreated control $\left(T_{1}\right)$. Hence, combination of polymer with Vitavax can effectively be utilized to prevent the rapid deterioration of the seed during storage thereby maintaining the quality for a longer period of time.
\end{abstract}

Keywords: Polymer coating, seed coating, seed quality, storability, wheat

\section{Introduction}

Wheat (Triticum aestivum L.) is an important cereal grain crop of the Gramineae family, widely cultivated and consumed all around the globe with an area and production of 224.49 million hectares and 792.4 million tons respectively (Anonymous 2021). In India, it is the second leading cereal crop after rice, with an area and production of 32.0 million hectares and 108.0 million tons respectively (Anonymous 2021). Storing seeds after harvest till the subsequent cropping season without compromising quality is of prime importance for successful seed production. However, a seed is a living entity that gets impacted by the environment around it which makes the storage of seeds challenging. In storage, vigor and viability of seed are not only persuaded by the genera or the variety but also influenced by different environmental factors (Doijode 1990). Other constraint affecting the storability of the seed include microflora, which is mainly responsible for the degradation of carbohydrates, protein and other food reserves leading to reduced seed germination and vigour. Generally, seeds after attaining their physiological maturity tend to proceed towards aging and thus the process of deterioration 
begins as soon as seeds are harvested (Abdul - Baki and Anderson, 1973).

Deterioration of seeds during storage is an inevitable process that can be observed by per cent reduction in the germination of seed, seedling vigour, and viability which subsequently lead to seed death or in production of weak seedlings (Tilebeni and Golpayegani, 2011). Deterioration of seeds can lead to various impairments in the metabolic activities, enzymatic activity, compositional changes and phenotypic variations during seed ageing but the pace of seed deterioration can be decelerated either by storing the seeds under the optimum ambient conditions or by encasing the seeds with polymer films along with seed treatment chemicals. Providing optimum conditions for storage involve a huge sum of money, therefore, seed treatment becomes the best feasible approach to maintain the quality of seeds.

Nowadays, various quality enhancing treatments are given to the seed lot before storage as well as during sowing, among them seed coating is the technique wherein external material viz, polymer, insecticides, and fungicides are directly applied to the seed without making drastic changes in the size, weight or shape of the seeds. Seed coating is easy to apply, diffuses quickly and is harmless to the seedling during germination. Homogenous film coating with polymer allows better adherence of seed treatment chemicals thus ensuring dust-free handling of seeds. Further, the biodegradable nature of the coating makes it eco-friendly and also helps in providing protection from pathogen attack as well as from the stress imposed due to accelerated ageing (Baig $e t$ al., 2012). It has been observed that the quality of wheat seeds degrade rapidly mainly when untreated seeds are stored under non- optimum conditions using improper packaging material. So, keeping this in view, the present investigation was formulated to study the effectiveness of treating wheat seeds with polymer alone as well as in various combinations with insecticides and fungicides to understand their influence on the storability and maintaining the quality of seed.

\section{Materials and Methods}

The current investigation was conducted at the Department of Seed Science and Technology, CSKHPKV Palampur. Seed treatment was done manually during December 2018 on carry-over seeds harvested from Rabi season 2017-18.
One $\mathrm{kg}$ of seeds per treatment was kept in HDPE (highdensity polyethylene) interwoven bag. The details of the treatment are depicted in Table 1. After coating the seeds with different treatments, the seeds were kept for shade drying for 72 hours at room temperature and moisture content was brought back to the original i.e., around $10 \%$ before packing the seeds for storability. The coated seeds of various treatments were packed in HDPE (highdensity polyethylene) interwoven non-laminated bags and stored under ambient conditions for twenty-four months (December 2018 to December 2020) at Department of Seed Science and Technology, CSKHPKV, Palampur. The experiment was laid out in Completely Randomised Design (CRD) with three replications. The evaluation for seed quality parameters was made at bi-monthly interval for twelve months ( $12^{\text {th }}$ to $24^{\text {th }}$ months) i.e., from January 2020 to December 2020. The seeds were drawn at random from each treatment bag at bimonthly intervals for analysing the seed quality parameters as detailed.

Germination test was conducted using 100 seeds drawn at random from each treatment replication-wise (three replications) by adopting Blotter paper method as described by ISTA procedures (Anonymous 1999). Seeds were incubated in germinator at the temperature of $25 \pm 1^{\circ} \mathrm{C}$ and relative humidity of 90 per cent. Germinated seeds were counted on $8^{\text {th }}$ day and germination percentage was calculated using the following formula:

Germination \% $=$ Number of germinated seeds $/$ Total number of seeds $\times 100$

Field emergence count was taken on the $14^{\text {th }}$ day after sowing and the emergence percentage was calculated taking into account the number of seedlings emerged above the soil surface.

10 normal seedlings from the germination test were selected from each replication of the treatment for measuring the seedling length and the average was worked out in centimetres. The same ten normal seedlings were then used for seedling dry weight measurements. The seedlings from each replication of the treatment were put in butter paper pocket and kept in hot air oven at $70^{\circ} \mathrm{C}$ for 18 hours. The dry weight of the seedlings was recorded and expressed in grams. The seedling vigour index -I was calculated as per the formula (Germination $(\%) \times$ Seedling length $(\mathrm{cm})$ ) and vigour index-II was calculated as per 
the formula [Germination $(\%) \times$ Seedling dry weight $(\mathrm{g})$ ] suggested by (Abdul Baki and Anderson, 1973).

Speed of germination was determined on the basis of daily germination count and was calculated by the following formula.

Speed of germination $=\mathrm{n} 1 / \mathrm{d} 1+\mathrm{n} 2 / \mathrm{d} 2+\mathrm{n} 3 / \mathrm{d} 3+--------$

Where, $\mathrm{n}=$ number of germinated seeds, $\mathrm{d}=$ number of days.

Table 1. Treatment details
Moisture of seeds was recorded content in percentage using the moisture meter (Non - Destructive Moisture Meter PM 600). The laboratory data were subjected to statistical analysis using software OPSTAT (Sheoran et al. 1998). The data on germination (\%), field emergence (\%) were transformed into arcsine value, and transformed data were used for statistical analysis.

\begin{tabular}{|c|c|}
\hline Treatment & Description \\
\hline $\mathrm{T}_{1}$ & Uncoated seeds - Control \\
\hline $\mathrm{T}_{2}$ & Polykote @ $3 \mathrm{ml} / \mathrm{Kg}$ of seeds, diluted with $5 \mathrm{ml}$ of water \\
\hline $\mathrm{T}_{3}$ & Flowable Thiram was applied on seeds @ $2.4 \mathrm{ml} / \mathrm{Kg}$ of seeds \\
\hline $\mathrm{T}_{4}$ & $\begin{array}{l}\text { Polykote @ } 3 \mathrm{ml} / \mathrm{Kg} \text { of seeds, diluted with } 5 \mathrm{ml} \text { of water and flowable Thiram @ } 2.4 \mathrm{ml} / \mathrm{Kg} \text { of } \\
\text { seeds }\end{array}$ \\
\hline $\mathrm{T}_{5}$ & Vitavax $200 @ 2$ g/Kg of seeds \\
\hline $\mathrm{T}_{6}$ & Polykote@3 ml/Kg of seeds diluted in $5 \mathrm{ml}$ of water and Vitavax $200 @ 2 \mathrm{~g} / \mathrm{Kg}$ of seeds \\
\hline $\mathrm{T}_{7}$ & Imidacloprid @ 4 ml/Kg of seeds \\
\hline $\mathrm{T}_{8}$ & Polykote@ $3 \mathrm{ml} / \mathrm{Kg}$ of seeds and Imidacloprid @ $4 \mathrm{ml} / \mathrm{Kg}$ of seeds \\
\hline $\mathrm{T}_{9}$ & $\begin{array}{l}\text { Polykote @ } 3 \mathrm{ml} / \mathrm{Kg} \text { of seeds, diluted with } 5 \mathrm{ml} \text { of water, followed by flowable Thiram @ } 2.4 \mathrm{ml} / \\
\mathrm{Kg} \text { of seeds and Imidacloprid @ } 4 \mathrm{ml} / \mathrm{Kg} \text { of seeds }\end{array}$ \\
\hline $\mathrm{T}_{10}$ & $\begin{array}{l}\text { Polykote @ 3ml/Kg of seeds, diluted with } 5 \mathrm{ml} \text { of water, followed by Vitavax } 200 @ 2 \mathrm{~g} / \mathrm{Kg} \text { of } \\
\text { seeds and Imidacloprid @ } 4 \mathrm{ml} / \mathrm{Kg} \text { of seeds }\end{array}$ \\
\hline
\end{tabular}

\section{Result and Discussion}

Seed coating produced significant effect in all the seed quality parameters evaluated in the laboratory. After 24 months of storage, a significantly higher germination percentage was recorded for all the treatments over control $(86.33 \%)$. Irrespective of treatments, average seed germination declined gradually from 91.43 to 89.13 per cent by the end of 24 month of storage (Table 2). After 24 months of storage, seed treated with a combination of polymer@ $3 \mathrm{ml}$ per Kg of seed and Vitavax $200 @ 2$ g per $\mathrm{Kg}$ of seed $\left(\mathrm{T}_{6}\right)$ exhibited significantly highest germination $(93.00 \%)$ that was at par with $\left(\mathrm{T}_{5}\right)$ Vitavax $200 @ 2$ g per $\mathrm{kg}$ of seed (92.00\%) (Fig. 1). At the end of storage period, higher germination observed in treated seeds may be due to the suppressive nature of chemicals on storage pathogens. Polymer might have acted as a protected shield warding off the deteriorative effects of relative humidity and oxygen on seed. Due to reduced exposure to external deteriorative agents, the seed germinability was maintained for a comparatively longer period of time. The outcomes are consistent with the findings of Roshna et al. (2013) in wheat, Rathinavel (2015) in cotton, Patel et al. (2017) in soybean, Dixit et al. (2018) in wheat and Sharma et al. (2017) in corn. 


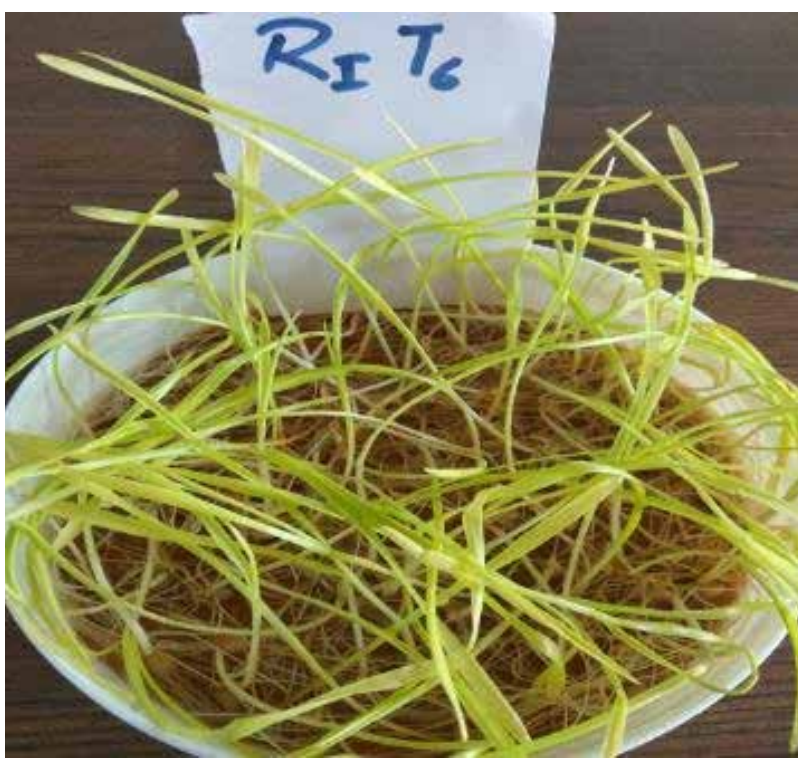

T6 - polymer + Vitavax 200 (after 14 months of storage)

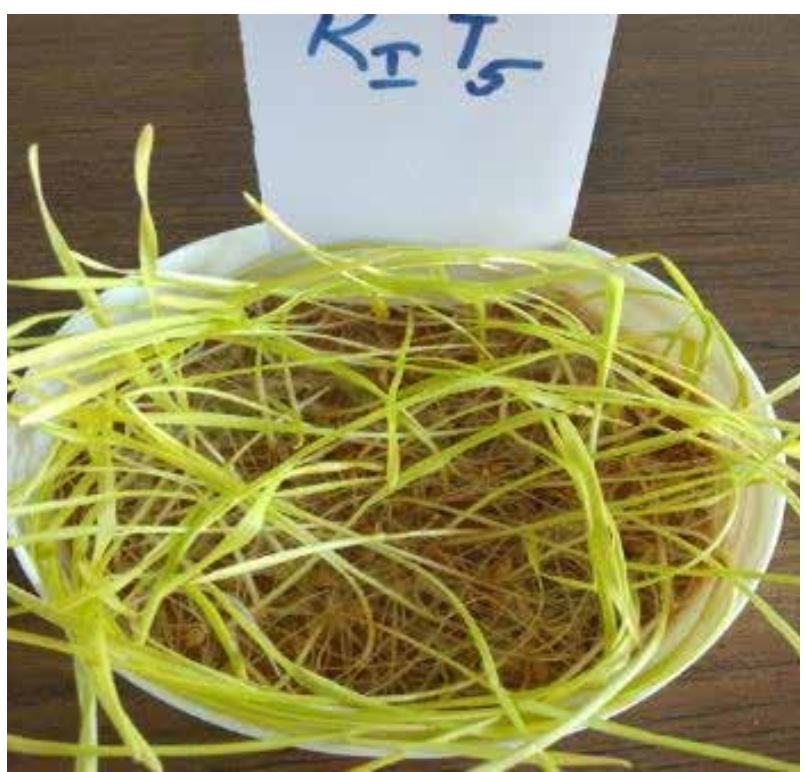

T5 - Vitavax 200 (after 14 months of storage)

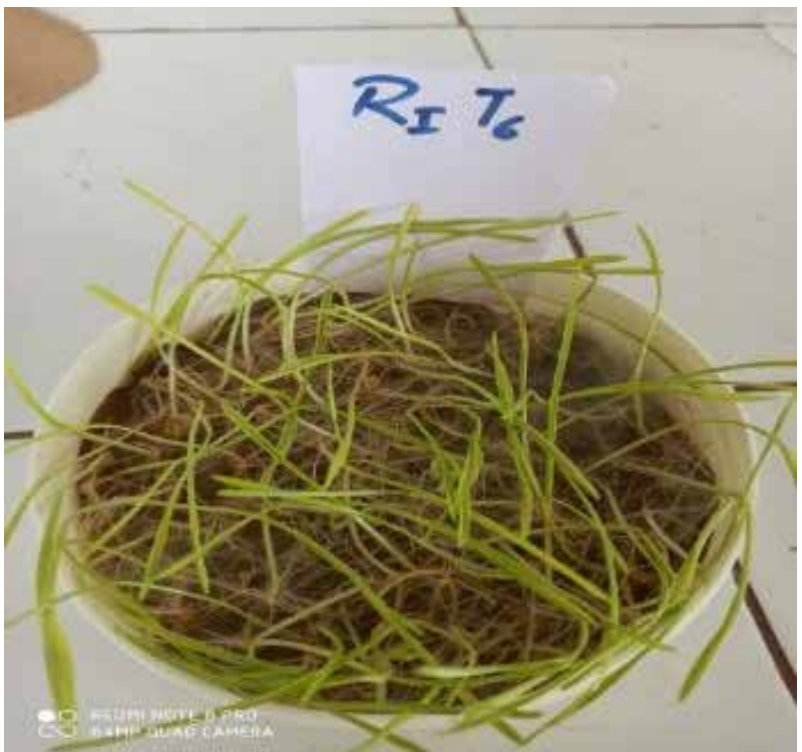

T6 - polymer + Vitavax 200 (after 24 months of storage)

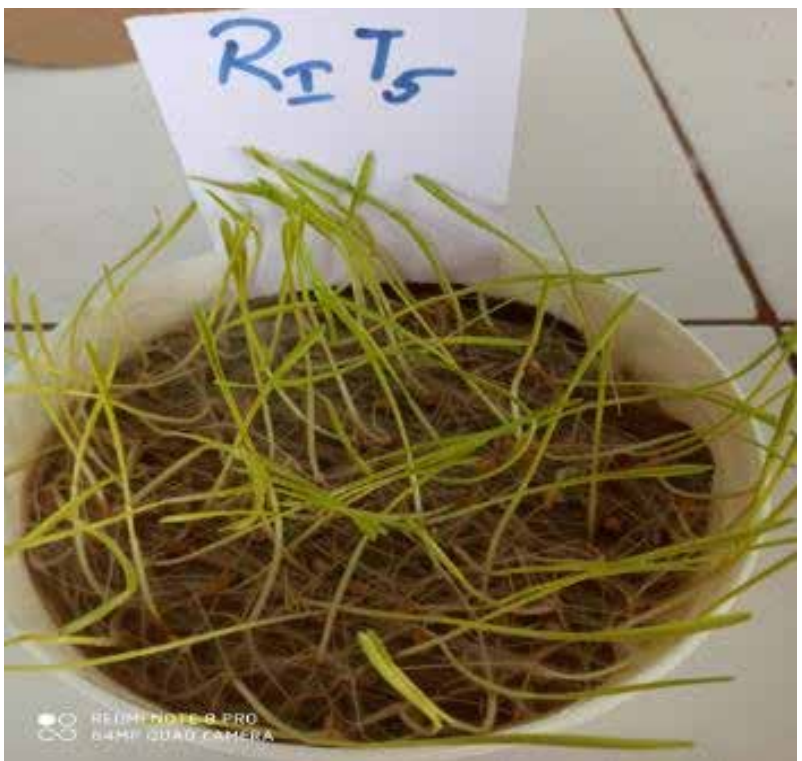

T5 - Vitavax 200 (after 24 months of storage)

Fig. 1. Representing the treatment T6 (polymer @ 3ml per Kg of seed + Vitavax $200 @ 2$ g per Kg of seed) and T5 (Vitavax $200 @ 2 \mathrm{~g}$ per $\mathrm{Kg}$ of seed) significantly superior over T1 - control

A similar trend was observed in the case of field emergence which declined progressively with the advancement of storage duration, irrespective of seed coating treatments (Table 2). Significantly higher field emergence (82.00\%) was documented in $\mathrm{T}_{6}$ (polymer @ $3 \mathrm{ml}$ per $\mathrm{Kg}$ of seed and Vitavax $200 @ 2$ g per Kg of seed) which was at par with $\mathrm{T}_{5}$ (Vitavax $200 @ 2 \mathrm{~g} \mathrm{Kg}^{-1}$ of seed)- (78.33\%) at the end of 24 months of storage. The polymer and fungicide protected the seed from pathogen and pest thereby keeping all the vital organs and storage metabolites intact which ultimately aid in sustaining field emergence. Similar findings were reported by Sharma et al. (2017) in hybrid maize and Padhi et al. (2017) in rice. 


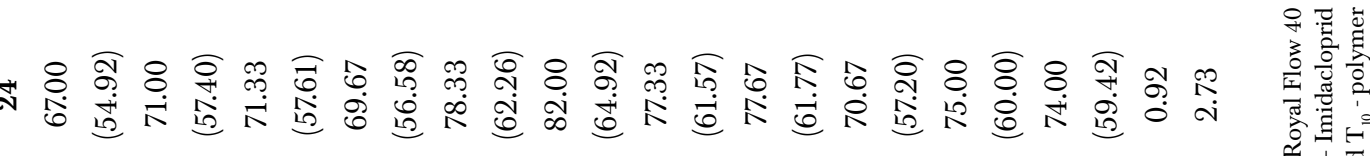

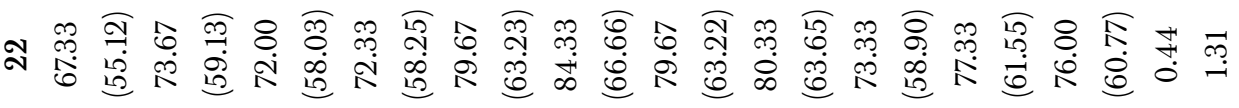

踏

焉焉离

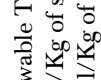

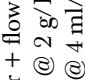

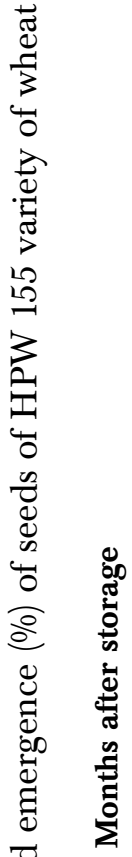

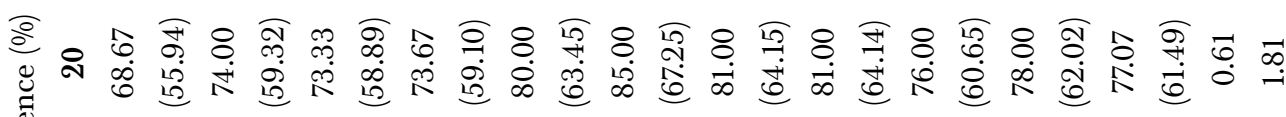

离

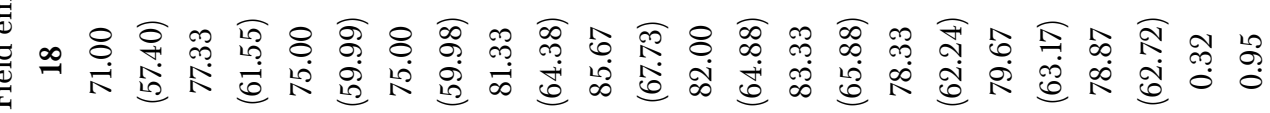

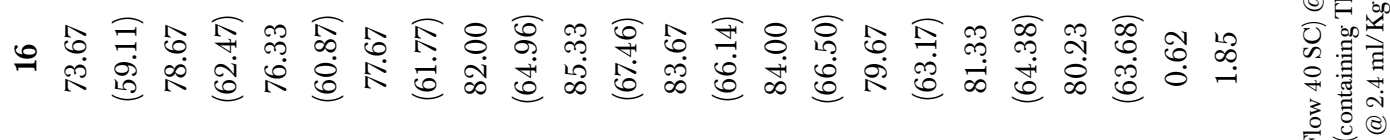

范

要通

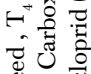

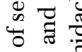

so

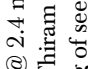

(e)

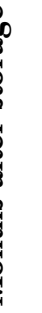

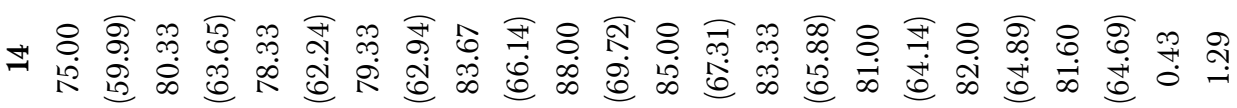

플유

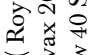

局要运

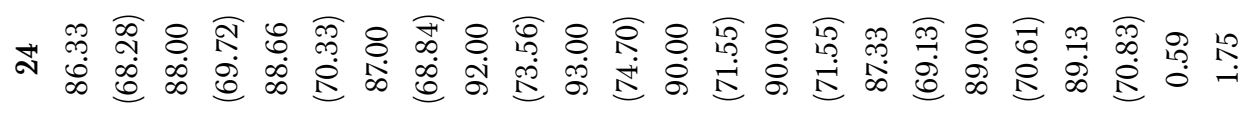

言苋焉

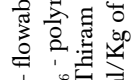

0
-80

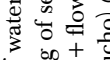

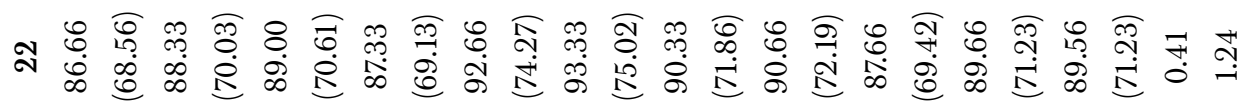

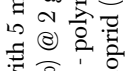

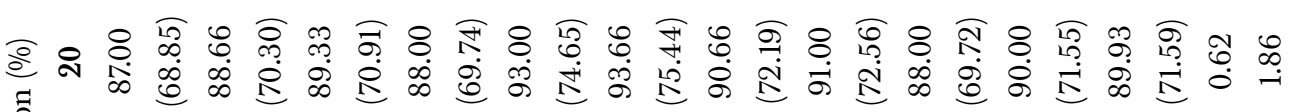

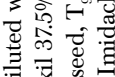
:

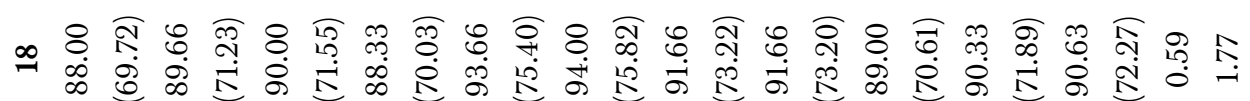

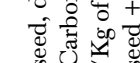

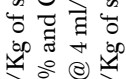

a

(8) 돈

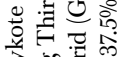

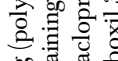

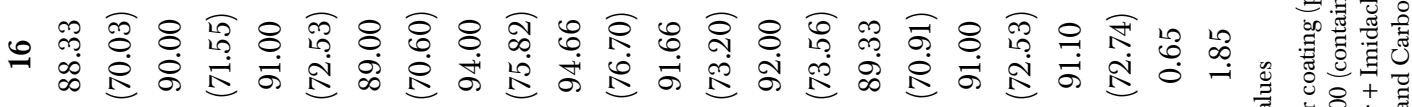

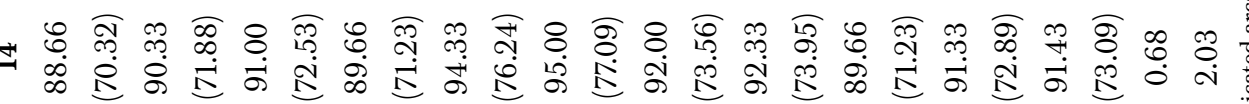

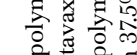

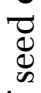

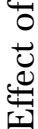

$\frac{i}{\stackrel{0}{\pi}}$

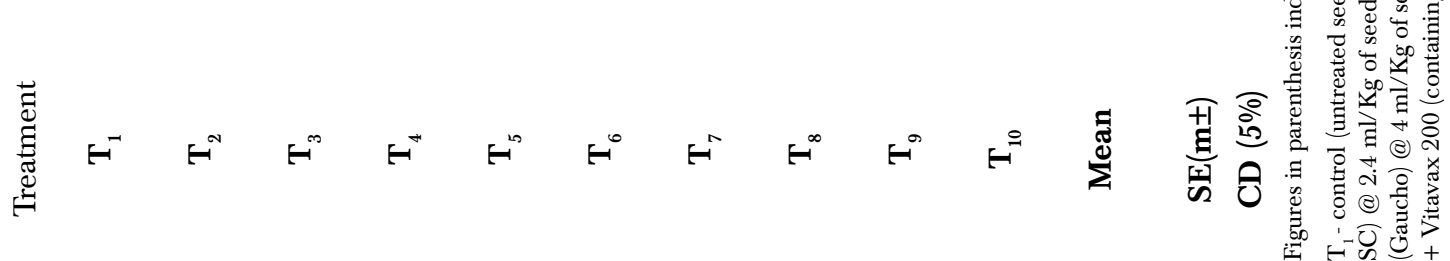


The mean seedling length observed at the beginning and at the end of storage period was 16.87 and $15.35 \mathrm{~cm}$, respectively. A decline in seedling length was observed irrespective of the coating treatments. The decrease in seedling length over time may be attributed to age induced decline in germination, and damage caused by toxic metabolite accumulation which might have hindered the seedling growth. The seedling length (cm) varied significantly throughout the storage period for different seed coating treatments (Table 3). The treatment $\mathrm{T}_{6}$ (polymer + Vitavax $200 @ 2 \mathrm{~g}$ per Kg of seed) exhibited highest seedling length $(16.06 \mathrm{~cm})$ at the end of 24 months of storage, which was at par $(16.00 \mathrm{~cm})$ with $\mathrm{T}_{5}$ (Vitavax $200 @ 2 \mathrm{~g}$ per Kg of seed). Coating with polymer and fungicide reduced the rate of deterioration by protecting the seed against environmental moisture and storage fungi. This granted protection might have contributed in safeguarding the metabolites for a longer period of time. These metabolites transformed to vigorous growth, thereby exhibiting higher seedling length. Similar outcomes were reported in maize by Kaushik et al. (2014) in maize, Sharma et al. (2017) in corn, Padhi et al. (2017) in rice, Goswami et al. (2017) in soybean, Roopashree et al. (2018) in chickpea, Parihar et al. (2019) in okra, Kotia et al. (2020) in radish.

The effect of several seed treatments on seedling dry weight $(\mathrm{g})$ after 24-month storage period is depicted in Table 3. The data observed the similar trend as witnessed in seedling length. With the advancement of storage period, the dry matter of the seedlings decreased. This reduction in dry matter of seedling could be attributed to natural ageing, resulting in seed decomposition, reduced germination percentage and seedling length. The treatment $\left(\mathrm{T}_{6}\right)$ polymer + Vitavax $200 @ 2 \mathrm{~g}$ per Kg of seed exhibited significantly highest seedling dry weight $(0.0116$ g) which was at par with $\mathrm{T}_{5}$ Vitavax $200 @ 2 \mathrm{~g}$ per $\mathrm{Kg}$ of seed $(0.0115 \mathrm{~g})$ at the end of storage period. This may be due to adequate reserves present in the seed which were transferred to the embryo and utilized in the growth and development of the seedling. Similar outcomes have been confirmed by the study conducted by Thakur and Dhiman (2016) on soybean.

Regardless of seed treatment, the vigour of stored seed deteriorated as the storage period progressed. The mean vigour index-I and vigour index-II was 1543 and 1.127

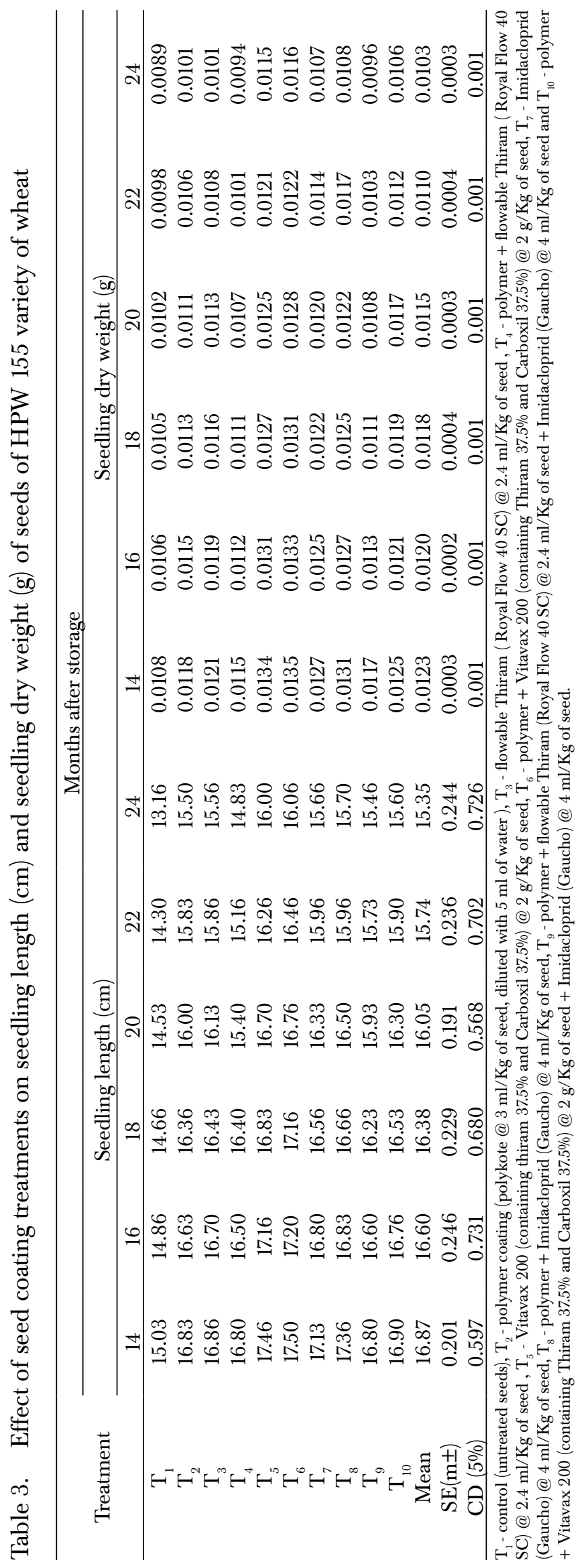


respectively, at the start and 1370 and 0.922 , respectively, at the end of the storage period. The drop in vigour index-I could be attributable to a decrease in seedling length and germination, while that of vigour index-II can be attributed to a decrease in seedling dry weight and germination percentage (Table 4.). The decrease in vigour index-I and II may be related to natural ageing, which resulted in decreased germination, dry matter accumulation in seedlings, and seedling length. Throughout the storage period, the seedling vigour index - I changed dramatically, wherein significantly higher seedling vigour index - I was observed in treatment $\mathrm{T}_{6}$ (a combination of polymer and Vitavax 200 used as $2 \mathrm{~g}$ per $\mathrm{Kg}$ of seed) - (1494), that was at par with $\mathrm{T}_{5}$ (Vitavax $200 @ 2 \mathrm{~g}$ per Kg of seed) - (1472) (Fig. 2). A similar trend was observed for seedling vigour index - II where significantly highest value was observed for $\mathrm{T}_{6}$ (polymer and Vitavax 200 used as $2 \mathrm{~g}$ per $\mathrm{Kg}$ of seed) - (1.079), that was at par with $\mathrm{T}_{5}$ (Vitavax $200 @ 2 \mathrm{~g}$ per $\mathrm{Kg}$ of seed) - (1.058) (Fig. 3.). Higher vigour index in polymer treatment along with fungicide is due to better germination, seedling length and dry weight. In addition, the polymer treatment protects the seed against the stress associated with rapid ageing. The polymer barrier also defends the seed against fungal invasion. In pigeon pea, a similar outcome was reported by Kumar et al. (2013).

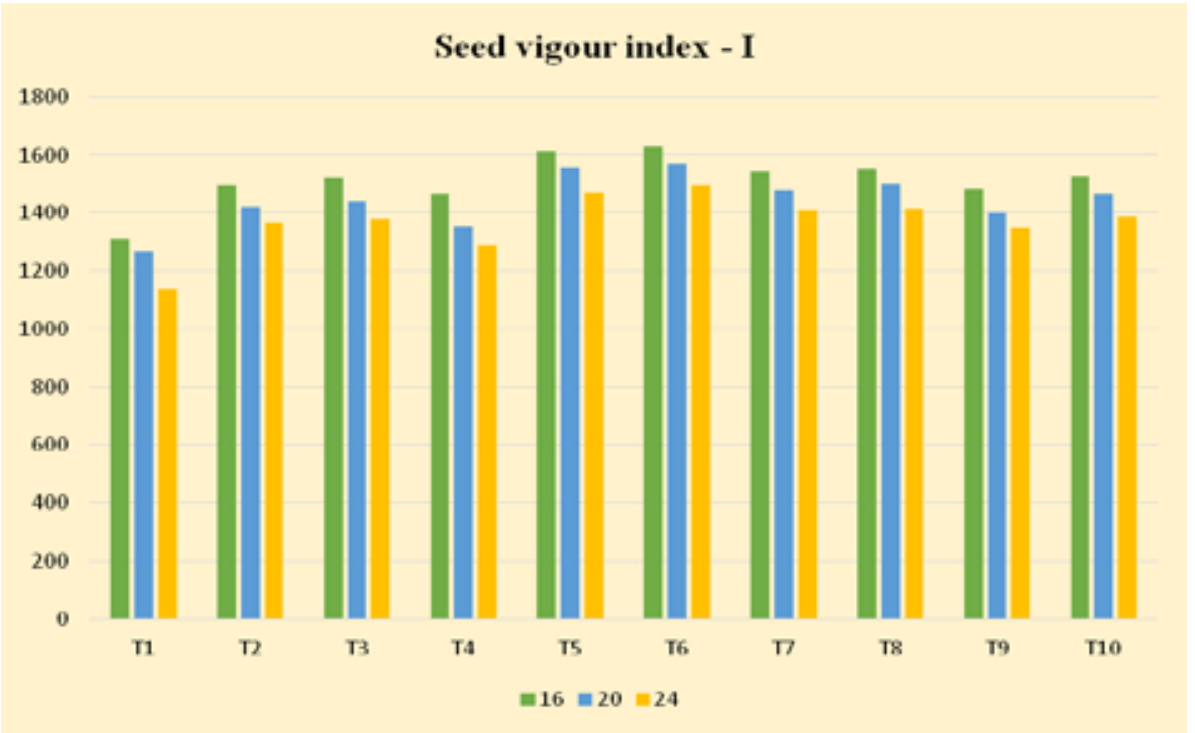

Fig. 2. Effect of seed coating treatments on seedling vigour index-I during storage in wheat variety HPW 155.

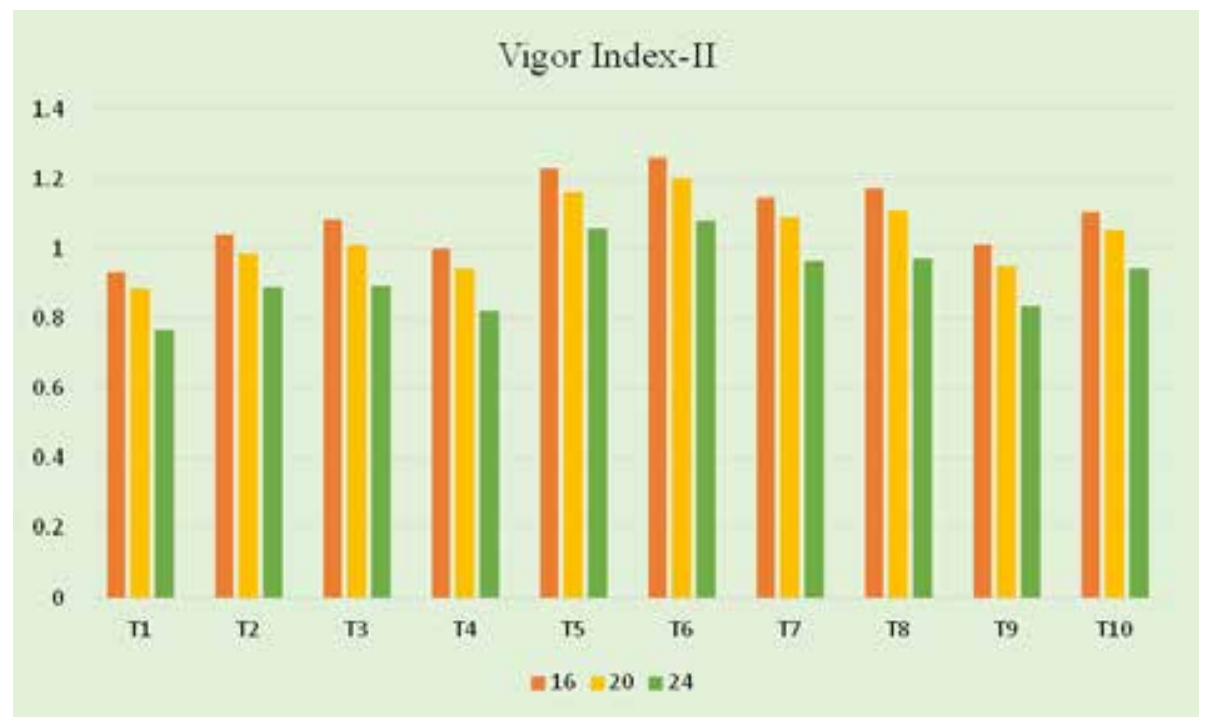

Fig. 3. Effect of different seed treatments on seedling vigour index-II during storage in wheat variety HPW 155 . 

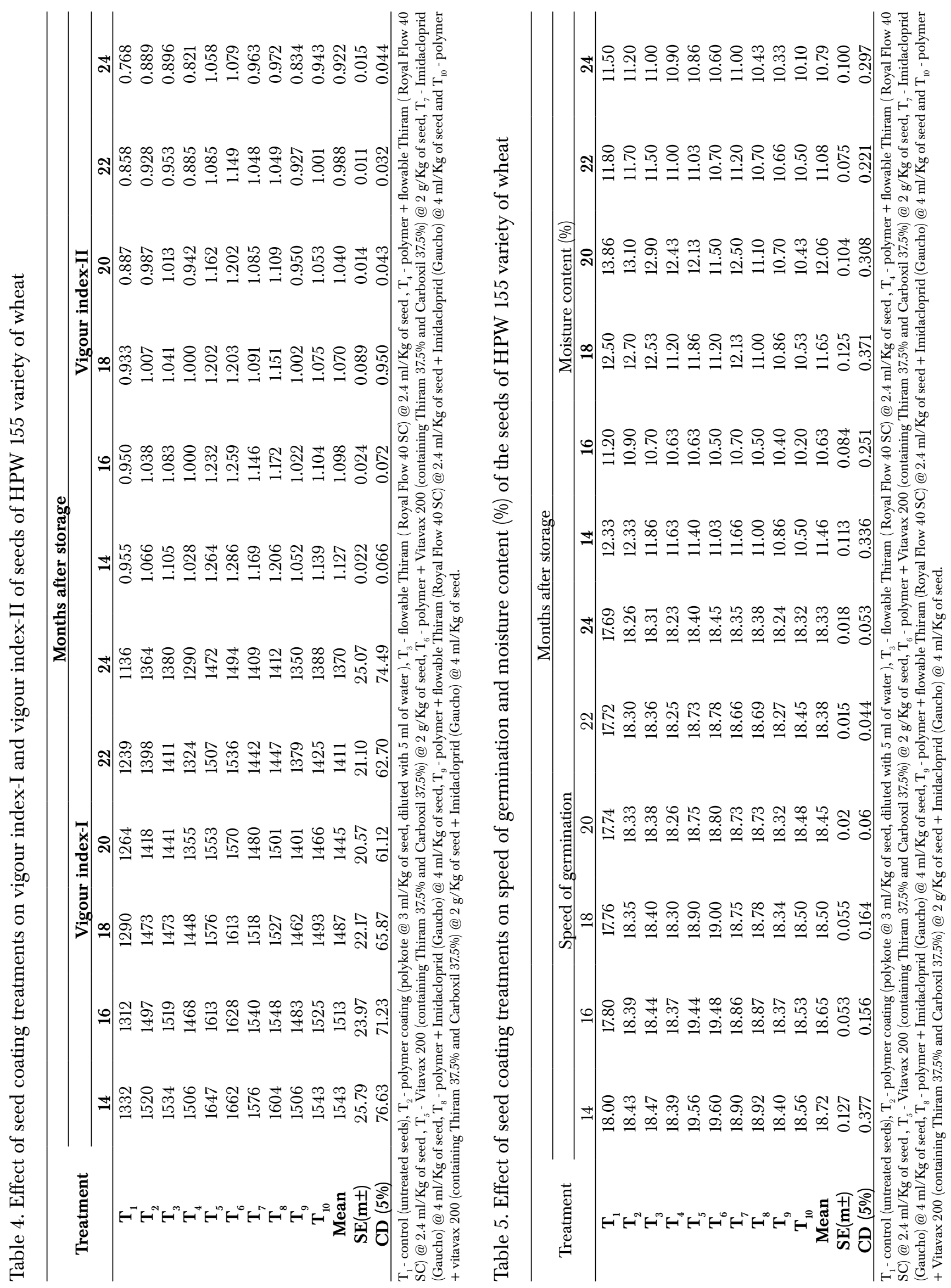
Irrespective of the seed treatments, speed of germination gradually declined with advancement in the storage period. The average value for the speed of germination declined from 18.72 to 18.33 (Table 5). The reduction in the speed of germination with the passage of time could be attributed to age induced deteriorative processes. After 24 months of storage, significantly highest speed of germination was recorded in treatment $\mathrm{T}_{6}$ - polymer @ $3 \mathrm{ml} / \mathrm{Kg}$ of seed + Vitavax $200 @ 2 \mathrm{~g} / \mathrm{Kg}$ of seed (18.45) which was at par with $\mathrm{T}_{5}$ - Vitavax $200 @ 2 \mathrm{~g} / \mathrm{Kg}$ of seed polymer (18.40). Similar results were also reported by Kunkur (2006) in cotton, Padhi et al. (2017) in rice, Sharma and Dhiman (2017) in paddy, Parihar et al. (2019) in okra, Prasher et al. (2020) in okra, and Kotia et al. (2020) in radish seeds.

During the storage period, the moisture content $(\%)$ grew and dropped steadily in response to changes in the ambient temperature and relative humidity. The moisture content recorded at the start of the storage period (January 2020) and at the end of the storage period (December 2020) was 11.46 per cent and 10.79 per cent, respectively (Table 5). After 24 months of storage in laboratory, lowest moisture content $(10.10 \%)$ was documented for $\mathrm{T}_{10}$ polymer + Vitavax $200 @ 2$ gram/Kg + Imidacloprid @ 4 millilitre $/ \mathrm{Kg}$ of seed, that was at par with $\mathrm{T}_{9}$ - a mix of polymer, flowable Thiram @ $2.4 \mathrm{ml}$ per Kg (10.33\%). The moisture content per cent of the seed altered as the storage period progressed. Under the prevalent storage conditions, particularly during the night, atmospheric moisture as well as relative humidity swings, influencing the moisture content of the seed lot, but wherein the pores in seeds coated with a polymer and chemical get covered consequentially preventing the entry of water in the seeds. Udbal et al. (2014) in sunflower seeds, Thakur and Dhiman (2016) in soybean, and Kotia et al. (2020) in radish reported similar results in their respective investigations.

\section{Conclusion}

From the current investigation, it can be concluded that seed ageing is an inexorable and irreplaceable process. It cannot be stopped but can successfully be delayed keeping the seed in acceptable limits of germination, field emergence and vigour. The treatment (T6) polymer + Vitvax $200 @ 2$ g/Kg of seeds significantly recorded superiority over all the other treatments in maintaining the quality attributes viz., germination, field emergence, seedling length, seedling dry weight and vigour till the end of 24 months of storage. Hence, combination of polymer with vitavax can effectively be utilized to prevent the rapid deterioration of the seed during storage thereby maintaining the quality for a longer period of time.

\section{Acknowledgements}

The authors are thankful to the Department of Seed Science and Technology, CSKHPKV, Palampur for providing necessary laboratory facility and support for carrying out the study.

\section{Conflict of Interest}

Author declare that they have no conflict of interests.

\section{Ethical Compliance Statement}

NA

\section{Author's Contribution}

Conceptualization of research ( $\mathrm{RC}, \mathrm{KCD}, \mathrm{RK})$; Designing of the experiments (KCD, RK, RC); Contribution of experimental materials (KCD, RC); Execution of field/lab experiments and data collection (RC, KCD, RK); Analysis of data and interpretation (KCD, RK, RC); Preparation of the manuscript (RC, KCD, RK).

\section{Reference}

1. Abdul Baki AS and JD Anderson. 1973. Vigour deterioration in soybean by multi criteria. Crop Science 13: 630-633.

2. Anonymous. 2021. Foreign Agriculture Services, U.S. Department of Agriculture (USDA), USA.

3. Anonymous 1999. International rules for seed testing. Seed Science Technology 27: 27-32.

4. Baig I, NK Biraderpatil, BT Ninganur and RH Patil. 2012. Effect of fungicides and polymer coating on storability of soybean seeds. Jawaharlal Nehru Krishi Vishwa Vidyalaya Research Journal 46:78-83.

5. Dixit S, P Singh, CB Singh, A Kumar and VK Yadava. 2018. Effect of seed coating treatments on germination and vigour of wheat (Triticum aestivum L.) during ambient storage. Journal of Pharmacognosy and Phytochemistry 7(3): 1145-1147.

6. Doijode SD. 1990. The influence of storage containers on germination of onion seeds. Journal of Maharashtra Agriculture University 15: 34-35. 
7. Goswami AP, K Vishnukant, M Chander and S Ravi. 2017. Effect of seed coating, storage periods and storage containers on soybean (Glycine $\max$ (L.) Merill) seed quality under ambient conditions. Journal of Applied and Natural Science 9: 598-602.

8. Kaushik SK, AK Rai and V Singh 2014. Seed quality of maize with polymer film coating in storage. International Journal of Innovative Research in Science, Engineering and Technology 3: 14353-14358.

9. Kotia K, KC Dhiman and R Kanwar. 2020. Effect of seed treatments on quality and storability of radish (Raphanus sativus L.) seeds. Agriculture Research Journal 57: 414-424.

10. Kumar V, BS Vyakaranahal, P Dhananjaya, H Yegappa and AM Asha. 2013. Effect of seed polymer coating on field performance and quality of pigeon pea (Cajanus cajan (L.) millsp). Environment and Ecology 31: 43-46.

11. Kunkur V. 2005. Effect of fungicide, insecticide and polymer coating on storability of cotton seeds. Master's Thesis, University of Agricultural Sciences, Dharwad, India, $82 \mathrm{p}$.

12. Padhi SK, S Behera, SP Mishra, AK Padhiary and B Nayak. 2017. Effect of seed coating materials on seed quality during storage of paddy. Journal of Pharmacognosy and Phytochemistry 6(6): 1263-1279.

13. Parihar P, KC Dhiman, RK Kapila and R Kanwar.2019. Effect of coating on quality of okra seeds in storage. Seed Research 47:36-43.

14. Patel JB, S Jyoti, CA Babariya, RR Rathod and VJ Bhatiya. 2017. Effect of different storage condition and seed treatments on seed viability in soybean (Glycine $\max (\mathrm{L})$ Merr.). Journal of Applied and Natural Science 9(1): 245-252.

15. Rahraw R, PK Rai, A Kumar, BA Singh, AK Chaurasia and N Bala. 2013. Influence of polymer seed coating, biocides and packaging materials on storability of wheat (Triticum aestivum L.) Report and Opinion 5(12): 51-55.
16. Rathinavel K. 2015. Extension of shelf life of cotton (Gossypium hirsutum L.) seeds through polymer coating under ambient storage condition. Indian Journal of Agricultural Research 49: 447-451.

17. Roopashree B, RB Jolli, SS Ashok, BN Motagi.2018. Effect of Polymer coating and fungicide on storage performance of kabuli chickpea varieties. International Journal of Current Microbiology and Applied Sciences 7: 954-961.

18. Sharma A. 2017. Effect of seed coating with synthetic polymer and chemicals on seed quality and storability of rice (Oryza sativa L.). Master's Thesis, Department of Seed Science and Technology, CSK Himachal Pradesh KrishiVishvavidalaya, Palampur, India, 52 p.

19. Sharma J, KC Dhiman, JK Sharma and R Kumar. 2017. Effect of coating on seed quality of quality protein maize hybrid and storability under hill conditions. Seed Research 45: 147-155.

20. Sheoran OP, DS Tonk, LS Kaushik, RC Hasija and RS Pannu.1998. Statistical Software Package for Agricultural Research Workers. Recent Advances in information theory, Statistics and Computer Applications by DS Hooda \& RC Hasija, Department of Mathematics Statistics, CCS HAU, Hisar (139-143).

21. Thakur S and KC Dhiman. 2016. Effect of seed coating with synthetic polymer and additives on storability of soybean seeds under mid hill condition of Himachal Pradesh. Himachal Journal of Agricultural Research 42: 34-40.

22. Tilebeni GH and A Golpayegani. 2011. Effect of seed aging on physiological and biochemical changes in rice seed (Oryza sativa L.). International Journal of Agricultural Science 1(3): 138-143.

23. Udbal N, R Hunje and P Kote. 2014. Effect of containers and seed treatments on storability of sunflower (Helianthus annuus L.). International Journal of Agricultural Sciences 10: 774-781. 